\title{
Research on the role of Teaching-research Universities Subject Librarian in University Library Construction
}

\author{
Guishan Zhang ${ }^{1, a}$ \\ ${ }^{1}$ Jilin Agricultural University, Changchun, Jilin, 130118
}

Keywords: Teaching-research universities library, Subject librarian, Role definition

\begin{abstract}
University library is the literature information center of subject construction, and it carries out dual responsibility of providing literature information guarantee for teaching and scientific research. University library should vigorously implement the 'subject librarian' system, embed discipline construction and the whole process of teaching and scientific research actively, strengthen the construction of high-level subject information resources, carry out multi-level, multiple carrier, networked, personalization and service methods and service methods services integration disciplines service to service for universities teaching and scientific research.
\end{abstract}

\section{Introduction}

Subject librarians first originated in the research level of university library of United States and Canada and at present university library at home and abroad generally have a subject librarian. Subject librarian who providing targeted, deep literature information service is the delegate of the university library, specifically making mouth contact with a faculty or subject, and take the initiative to embed the faculty or the students of academic disciplines. The first-class university must have the first-class discipline and the first-class discipline need to have a first-class library management and service. The teaching and research of teaching-research university is often around professional disciplines to expand, and the library is the service object, which main functions are also should be the collection, organization and cultivation of professional information and related disciplines professional information and service for teaching and research of academic disciplines. Therefore, the teaching research university library is the unique resources and capabilities taking subject service as the core, taking the subject information resources and technical equipment resources on as the basis and taking subject librarian as safeguard. Teaching-research university library should vigorously implement the 'subject librarian' system, be committed to subject librarian team building, improve the degree of specialization, take in-depth research, be familiar with the subject construction and teaching and research needs, actively participate in the discipline construction and the whole process for teaching and scientific research, strengthen the information resources construction of high-level subject, carry out multi-level, multiple carrier, networked, personalization and service methods and service methods services integration disciplines service to service for universities teaching and scientific research.

Among many elements of library core competence of teaching-research universities, talent is the key of core competitiveness and core competitiveness has a high degree of dependence on talents, in the final analysis library competition is the talent competition and the subject librarian system is a kind of new management concept and new service mode. Teaching-research university library determine their position, make their strategic decisions, and actively carry out subject librarian system according to the teaching and scientific research needs, improve their core competitiveness 
relying on the subject librarians and realize the effective management and high quality service of their own work.

\section{Subject Librarian and Library Development of Teaching-research University}

Teaching-research university subject librarian is the human resources guarantee of university library development. The transformation of science and technology into productive force is the precondition of producing benefits and promoting social progress and a large number of science and technology including some high and new technology is kept in the university library, and the timely transformation of science and technology into useful technological information to feed back to the user need information talents with professional knowledge, which not only can guarantee the normal operation of modern information processing equipment, but also can provide users with high quality information service. So it requires that the university library must establish a library team with rich professional knowledge, high comprehensive quality, mastering new technology of library and adapting to modern library work, besides, gradually cultivate the personnel in team into subject librarians and establish subject librarian system. Subject librarians master at least one professional discipline knowledge, and master books intelligence, has rich library theory and practical experience, which can provide a high level of literature information service for corresponding subjects and establish the differentiated competitive advantage, besides, the ideas, behavior, ability etc of the subject librarian will bring huge influence on library's core competitiveness. The establishment and perfection of the subject librarian system can greatly stimulate the sense of responsibility, curiosity and high degree of achievement subject for librarians and mobilize their working enthusiasm and creativity. In the practical work, constantly learning new knowledge and mastering new skills can promote the increase of overall quality and comprehensive quality of librarians, then to improve the development of teaching research university library.

Teaching-research University Subject Librarian Service Concept Representing the Future Development Direction of University Library Subject librarians adjust the service concept around the needs of users, in the process of service, carry out the ideology of Starting from User Requirements, and End in Customer Satisfaction', and seriously implement the service purposes of 'Everything for the Readers, For Readers' Everything, For All Readers', set up the service concept of 'Taking User as the Center' , respect the readers' personality, fully understand the reader demand and meet the reasonable requirements of the readers to the greatest extent. Besides, set up the concept of active service, warmly receive readers and initiatively understand, solicit, research, and satisfy the demand of readers, at the time of making better service condition, actively carry out individualized active information service, develop new readers and expand service areas, take service quality as the survival conditions, strengthen personalized service and characteristic service, eventually embedded the course of teaching and research development of discipline.

Subject Service is the Core of Library Development Service is the basic aim of teaching-research university library. The significance of library management and development of teaching-research universities lies in providing service for teachers and students. Subject service will become the backbone of library development and the core business of the library, and it is the core of library's core competitiveness. Subject service is the service method, in which subject librarian of various discipline participate in the teaching and research of academic disciplines readers according to their demand and the information resources of academic disciplines construction to organize and develop information resources deeply. By the means of various carrier, information technology and network, personalized service, multi-level service mode and integrated service method to provide personalized knowledge service. Subject service is deep and high level 
library service. Fundamental changes have taken place for the reader demand in the internet-age and people's access to information is no longer constrained to a single source, but have many choices, which beyond the limit of time and space. Subject librarians need take in-depth guidance for readers and be good at screening and utilizing literature and information, and carry on deep integration, exploration and processing of information resources according to the needs of users, besides by formulating information products of high quality, to constantly improve the level and efficiency of literature information service, promote the knowledge innovation and technological innovation, so as to improve the library development.

\section{Measures Should be Taken to Establish and Perfect the System of Subject Librarians for Teaching Research University}

Teaching research universities should set up subject librarian system, which is the expansion of service depth and breadth for teaching research university library and the enjoy of convenient and fast personalized service for readers. So establishing subject librarian system is welcomed for both library and readers. Though China's University library subject librarian system started late, it has achieved preliminary results. At present, the system of subject librarian of university library in the period of rapid development, in view of the present problems and insufficiency existing in the process of the set up and running of subject librarian system, we should take effective measures to ensure that the subject librarian system play a proper role in the teaching and scientific research of teaching research universities.

Establish subject librarian leading group and set up management mechanism. Subject librarian is a cooperative task, which is not only the cooperation between library and departments, but also the cooperation between different departments of library. Leading group is mainly engaged in the coordination and cooperation of between library and departments, and library's different departments, the content of which includes determining and adjusting service projects, appointment, training, evaluation of subject librarian, evaluation of service implementation effect, organization communication and publicity of service items. The implementation of appointment, service, evaluation indicators, training etc of subject librarian all need a series of management mechanism. 'Nothing can be accomplished without norms or standards', management mechanism is indispensable for the smooth work of subject librarian and is also a premise and guarantee for normal operation of the subject librarian system, which contains the qualification certification, post qualitative, treatment, responsibilities, work plan formulation and implementation, set up of evaluation system of subject librarian etc, besides, it is also the effective management means and basis, which plays the role of constraint and standardizing the behavior and it is also the code of conduct for subject librarians to carry out the work.

Establish examination evaluation system and incentive system for subject librarian. Establishing a scientific and perfect evaluation system is an important part of the subject librarian service management and the powerful guarantee of subject librarian system. Performance evaluation of subject librarian work not only depends on subject librarian work completion, but also depends on the satisfaction of teacher and student, that is to say, implementing two-way appraisal for subject librarians should not only accept library evaluation but also accept counterpart departments' assessment giving priority to user evaluation. Evaluation with both a benchmark of qualitative and quantitative will be more fully to reflect the status of subject librarian service. Therefore, in the management work, giving recognition and rewards to the librarian making achievements and contributions in the work will play important role of promoting, guiding and example. Avoid 'Eating from the Same pot' -- getting an equal share regardless of the work done, 
so as to avoid causing many negative emotions. To make the organic combination of short-term incentive and long-term incentive, establish and improve the system of library evaluation and increase the incentive ingredients of the compensation, by the means of turning promotion and training to become a kind of reward embodying library's recognition of their work performance, to motivate staff and encourage the excavations of talents intrinsic value and creativity to get in turn talent's identity and professional spirit for library.

Improve comprehensive quality of subject librarian in teaching research university in various ways. Subject librarian of teaching research university is the main body of subject service and is the most key factor to ensure service quality and set up library image in department. This is a challenging job, which needs to have very high comprehensive quality, at least should have a broad knowledge and information literacy, besides, to penetrate and combine with professional discipline, and also need higher skills of foreign language, computer, oral communication and social contact. Therefore, library should offer a variety of training and learning opportunities for subject librarian to promote their own learning and mutual learning between librarians. Send middle-aged and young business backbone with professional skills to take further study, encourage professional and technical personnel employed to study second degree, master, doctor etc., encourage personnel with a degree in library science to study knowledge of other disciplines to broaden the knowledge. Enhance the level of professional skills in a planned way, including the capacity of computer and network application, scientific research, education and information identification, selection, transformation, integration and public relations etc., at the same time, should encourage librarians to actively attend meetings and listen to core curriculum of school and department, understand the discipline development trend, promote the construction of subject librarian and library reservoir, refer to and consult other department to form intimate connection. Besides, establish subject librarian forum in library to provide exchange platform for subject librarian.

Reform unreasonable distribution system, improve the treatment of subject librarian. University librarian's income is generally low, and the corresponding social status is also relatively low, which is the key of causing shortage and dimission of domestic library talent. In colleges and universities, librarians belong to the school's paraprofessional school personnel, and they are in an inferior position compared with teachers and researchers in school distribution system. In that situation, the teaching research university library should strive high attention and strongly support of school leadership to reform the unreasonable distribution system and taking the complexity and knowledge content quantity of actual work content as the basis to make professional income become obviously higher than laypeople. Due to the complexity of subject librarian's work, which has a strong professional, and even has irreplace ability, therefore it is more necessary to improve the wages of subject librarians and make the income of subject librarian significantly higher than that of the general staff to reach to the level of professional teachers and researchers of each faculty. Only by this, libarary can attract talents and achieve the important value of the subject librarian and provide services for school's teaching and research.

\section{References}

[1] Z. S. Liu. Hong Kong Baptist University Library Subject Librarian System Research [J].Library, 2016,4:13-18 2011,21,(19):62-64

[2] X. W. Zhan. Core Competence of Subject Librarians on Building Library [J].Journal of Sichuan University of Science \& Engineering, 2008.23(12):68-70.

[3] G. S. Zhang. Research on the Needs of Knowledge Structure and Knowledge Hierarchy for University Library Subject Librarian [J]. Sci-Tech Information Development \& Economy 
[4]J. P. Yang. Research on University Library Core Competitiveness Based on Knowledge Management [J]. Library Research \& Work, 2010.167:18-21. 